\title{
Antioxidant and anti-inflammatory effects of phenolic rich Hylotelephium erythrostictum extracts
}

\author{
Sang Suk Kim ${ }^{1 *}$, Kyung Jin Park ${ }^{1}$, Seung Eun Lee ${ }^{2}$, Jeong Hoon Lee ${ }^{2}$, \\ Young Hun $\mathrm{Choi}^{1}$ \\ ${ }^{1}$ Citrus Research Institute, National Institute of Horticultural and Herbal Science, RDA, Jeju 63607, Korea \\ ${ }^{2}$ Department of Herbal Crop Research, National Institute of Horticultural and Herbal Science, RDA, Eumseong 27709, Korea
}

\section{폴리페놀 함량이 높은 Hylotelephium erythrosticum 추출물의 항산화 및 항염 활성}

\author{
김상숙 ${ }^{*} \cdot$ 박경진 $^{1} \cdot$ 이승은 $^{2} \cdot$ 이정훈 $^{2} \cdot$ 최영훈 $^{1}$ \\ ${ }^{1}$ 국립원예특작과학원 감귤연구소, ${ }^{2}$ 국립원예특작과학원 인삼특작부
}

\begin{abstract}
Hylotelephium erythrostictum is commonly used as a medicinal herb. In this study, $H$. erythrostictum leaf (HEL), branch (HEB), root (HER), and above ground (HEAG) extracts were evaluated for their antioxidant properties. The antioxidant activities were assayed by three methods based on scavenging of DPPH, ABTS and superoxide anion radical. HEAG extract showed the highest DPPH, ABTS, superoxide anion radical scavenging activities. HEAG extract also exhibited the highest phenolic content $(230 \mathrm{mg} / \mathrm{g}$ gallic acid equivalent). In our research for anti-inflammatory ingredients, the extract of HEAG inhibited the generation of nitric oxide (NO) in lipopolysaccharide (LPS)-stimulated RAW264.7 macrophage cells. To test the inhibitory effects of HEAG on pro-inflammatory cytokines, we conducted ELISA assay for the measuring the generation of tumor necrosis factor (TNF)- $a$, IL (interleukin)- $1 \beta$, and IL(interleukin)-6 in LPS-stimulated RAW264.7 macrophage cells. In these assays, HEAG ethanol extract showed a dose-dependent decrease in the production of TNF- $a$, IL-1 $\beta$, and IL-6. Based on these results, extract of HEAG could be the efficient candidate for anti-inflammatory agents.
\end{abstract}

Key words : Hylotelephium erythrostictum, anti-inflammatory, nitric oxide, cytokine

\section{서 론}

현대의 웰빙 트랜드는 건강을 중시하며 친환경을 내포한 자연주의 성향을 나타내고 있어 환경오염과 합성 화학성분 들에서 나타나는 부작용등에 대한 염려가 없는 순수 식물 성분에 대한 선호도가 높아지고 있다. 이러한 소비자의 건 강한 아름다움에 대한 욕구로 천연물 소재를 활용한 건강식

*Corresponding author. E-mail : sskim0626@korea.kr Phone : 82-64-730-4153, Fax : 82-64-730-4111

Received 8 September 2017; Revised 10 October 2017; Accepted 11 October 2017.

Copyright (c) The Korean Society of Food Preservation. All rights reserved.
품, 화장품, 생활용품 등의 개발이 활발히 진행 중이다. 천연물 소재는 오랫동안 사용되고 있는 약재와 같은 식 물을 이용하여 연구가 진행 중이며, 천연물에 함유되어 있 는 다양한 생리활성 성분들이 밝혀지고 있다(1-3). 특히 식 물 속에 존재하는 phytochemical은 각종 미생물, 해충 등과 같은 외부 이물질로부터 자신의 몸을 보호하는 역할을 하는 식물생리활성 영양소로 항산화, 항염, 항균 등에 대한 효능 이 알려지면서 피부친화적이고 안전한 화장품 소재개발에 적용하기 위한 연구가 진행 중이다(4,5). 또한 암, 동맥경화 증 및 염증을 예방과 감소에 크게 기여하는 것으로 보고되 고 있는 항산화 물질은 체내에서 생성되는 활성산소 감소에 영향을 미치는 것으로 알려지고 있다. 이에 활성산소를 조 절하거나 제거하는 능력을 지닌 생리활성물질에 대한 연구 
의 필요성이 대두되면서 천연물을 이용한 항산화 및 항염 소재 개발 연구가 활발히 진행되고 있다(6-8).

돌나무과에 속하는 다년생 초본으로 우리나라 전역에서 자생하며 한방에서는 경천이라고 불리는 뀡의비름 (Hylotelephium erythrostictum)을 연구하고자 하였다. 꿩의 비름은 피부병 치료에 사용되며 몸에 열을 내리고 해독작용 과 지혈 작용을 하는 것으로 알려져 민간에서는 뱀이나 독충에 물렸을 때 사용하며, 잎은 뒷면의 표피를 벗기고 피부 화농에 사용하기도 한다(9). 본 연구에서는 항산화 및 항염 활성의 천연물 소재 개발을 위해 꿩의비름 추출물 의 항산화 활성과 함께 염증반응을 효과적으로 억제시키는 항염 활성을 알아보고자 하였다.

\section{재료 및 방법}

\section{실험재료}

꿩의비름(H. erythrostictum) 뿌리, 잎, 줄기, 지상부 추출 물은 국립원예특작과학원 인삼특작부 추출물 은행에서 분 양 받아 사용하였다. 본 연구에 사용한 꿩의비름 뿌리와 줄기 추출물은 $50^{\circ} \mathrm{C}$ 에서 $100 \%$ 에탄올로 $24 \mathrm{~h}$ 동안 3 회 반복하여 추출하였고, 잎과 지상부는 $100 \%$ 메탄올로 24 $\mathrm{h}$ 동안 3 회 반복하여 추출하여 제조되었다.

\section{$\mathrm{DPPH}$ radical scavenging 활성 측정}

$\mathrm{DPPH}(1,1-$ diphenyl-2-picryhydrazyl) 라디칼 소거 활성 실 험은 Blois 방법(10)을 이용하여 사용하였다. $0.2 \mathrm{mM}$ 로 준 비된 DPPH $180 \mu \mathrm{L}$ 와 시료 $20 \mu \mathrm{L}$ 를 섞고 실온에서 10분간 방치한 후 SpectraMax ${ }^{\circledR}$ M3 Multi-Mode Microplate Reader(Molecular Devices, Sunnyvale, CA, USA)를 사용하 여 $517 \mathrm{~nm}$ 에서 흡광도를 측정하였다. $\mathrm{DPPH}$ 의 흡광도가 $50 \%$ 감소 할 때 나타나는 시료의 농도 $\left(\mathrm{SC}_{50}\right)$ 로 표시 하였으 며, 각 시료는 3 회 반복실험을 실시하여 평균값을 구하였다. 이 때 사용된 대조군으로는 vitamin C(Sigma-Aldrich, Damstadt, Germany)를 사용하였다.

$$
\text { Scavenging effect }(\%)=\left(1-\frac{\text { Asample-Ablank }}{\text { Acontrol }}\right) \times 100
$$

Acontrol : DPPH 용액의 흡광도

Asample : DPPH 용액과 시료 반응액의 흡광도

Ablank : 시료를 녹인 용매 흡광도

\section{ABTS radical scavenging 활성 측정}

ABTS(2,2'-azinobis(3-ethylbenzothiazoline-6-sulfonic acid)-diammonium salt) radical 소거활성은 $7.4 \mathrm{mM} \mathrm{ABTS}$ 와 $2.6 \mathrm{mM}$ potassium persulfate를 혼합 후 실온 암소에서
15 시간 동안 방치하여 radical을 형성시킨 후 이 용액을 734 $\mathrm{nm}$ 에서 흡광도 값이 $0.70 \pm 0.02$ 가 되도록 준비하였다. 준비 된 ABTS 용액 $180 \mu \mathrm{L}$ 에 추출물 $20 \mu \mathrm{L}$ 를 가하여 실온에서 15 분 동안 방치한 다음 $734 \mathrm{~nm}$ 에서 흡광도를 측정하였다. ABTS radical 소거활성은 시료 용액의 첨가구와 무첨가구 사이의 흡광도 차이를 백분율로 나타내었다.

$$
\text { Scavenging effect }(\%)=\left(1-\frac{\mathrm{B}-\mathrm{C}}{\mathrm{A}}\right) \times 100
$$
$\mathrm{A}: \mathrm{ABTS}$ 흡광도
$\mathrm{B}$ : $\mathrm{ABTS}$ 와 시료 반응액의 흡광도
$\mathrm{C}$ : 시료를 녹인 용매 흡광도

\section{Superoxide radical scavenging 활성 측정}

Superoxide radical 소거활성은 $\mathrm{Liu}$ 의 방법(11)에 따라 측 정하였다. 준비된 시료 $20 \mu \mathrm{L}$ 에 $30 \mathrm{mM}$ 의 Tris-HCl, buffer(pH 8.0) $100 \mu \mathrm{L}$ 와 $100 \mu \mathrm{M}$ 의 phenazine methosulfate (PMS)를 넣고 blank를 $560 \mathrm{~nm}$ 에서 측정한다. 그 다음 500 $\mu \mathrm{M}$ nitro blue tetrazolium(NBT) $40 \mu \mathrm{L}$ 와 $500 \mu \mathrm{M} \beta$ -nicotinamide adenine dinucleotide(NADH) $20 \mu \mathrm{L}$ 를 혼합한 후 흡광도를 측정한다. 즉, 비효소적으로 PMS/NADH로 유 발된 superoxide radical은 NBT를 자주색의 formazan으로 환원시키며, 생성된 formazan을 측정하기 위해 $560 \mathrm{~nm}$ 에서 10 분 동안 반응물의 흡광도를 측정하였다. 시료의 superoxide radical 소거활성은 [(흡광도시료 무첨가-흡광도시료)/흡광 도시료무첨가 $\times 100$ 의 공식으로 계산하였다.

\section{FRAP법에 의한 항산화 활성 측정}

추출물에 대한 FRAP(ferric reducing antioxidant power)법 에 의한 항산화 활성은 $300 \mathrm{mM}$ acetate buffer(pH 3.6), 40 $\mathrm{mM} \mathrm{HCl}$ 에 용해한 $10 \mathrm{mM}$ TPTZ(2,4,6-tripyridyl-s- triazine) 용액 및 $20 \mathrm{mM} \mathrm{FeCl} \cdot 7 \mathrm{H}_{2} \mathrm{O}$ 를 각각 10:1:1 (v/v/v)의 비율로 혼합하여 $37^{\circ} \mathrm{C}$ 의 수옥상에서 가온한 것을 $\mathrm{FRAP}$ 기질액으 로 사용하였다. 96 well plate에 시료액 $40 \mu \mathrm{L}, \mathrm{FRAP}$ 기질액 $100 \mu \mathrm{L}$ 및 증류수 $200 \mu \mathrm{L}$ 를 차례로 혼합하여 $37^{\circ} \mathrm{C}$ 에서 4 분 간 반응시킨 후 $593 \mathrm{~nm}$ 에서 흡광도를 측정하였으며, $\mathrm{FeCl}_{3} \cdot 7 \mathrm{H}_{2} \mathrm{O}$ 를 표준물질로 하여 얻은 표준검정곡선으로부 터 계산하였다.

\section{총 폴리페놀과 총 플라보노이드 함량 측정}

꿩의비름 추출물의 총 폴리페놀 함량 측정은 Folin-Denis (12)법을 이용하여 비색 정량하였다. 추출물 $100 \mu \mathrm{L}$ 에 증류 수 $900 \mu \mathrm{L}$ 를 넣어 total volume이 $1 \mathrm{~mL}$ 가 되도록 희석하였 다. 여기에 Folin-ciocalteus' phenol reagent $100 \mu \mathrm{L}$ 를 첨가하 여 실온에서 5분간 반응 후 $\mathrm{Na}_{2} \mathrm{CO}_{3}$ 용액 $(7 \%, \mathrm{w} / \mathrm{v}) 200 \mu \mathrm{L}$ 와 증류수 $700 \mu \mathrm{L}$ 를 넣어 실온에서 1 시간 반응시켰다. 흡광도 
는 SpectraMax $^{\circledR}$ M3 Multi-Mode Microplate Reader (Molecular Devices, Sunnyvale, CA, USA)를 이용하여 720 $\mathrm{nm}$ 에서 측정하였고, gallic acid를 이용하여 작성한 표준검 정곡선을 이용하여 추출물의 총 폴리페놀 함량을 나타내었 다. 총 플라보노이드 함량은 Moreno 등(13)의 방법을 이용 하여 정량하였다. 추출물 $15 \mu \mathrm{L}$ 에 diethylene glycol 150 $\mu \mathrm{L}, 1 \mathrm{~N} \mathrm{NaOH} 15 \mu \mathrm{L}$ 를 첨가하여 혼합한 후 상온에서 1 시간 반응시키고 UV-spectrophotometer를 사용하여 $420 \mathrm{~nm}$ 에서 흡광도를 측정하였다. Quercetin을 표준물질로 작성한 표준 검정곡선을 이용하여 추출물의 총 플라보노이드 함량을 나타내었다.

\section{세포배양}

Korean Cell Line Bank(KCLB, Seoul, Korea)로부터 분양 받아 사용한 RAW264.7 murine macrophage cell은 $37^{\circ} \mathrm{C}$, $5 \% \mathrm{CO}_{2}$ 항온기에서 $1 \%$ penicillin/streptomycin과 $10 \%$ fetal bovine serum(FBS)이 함유하는 Dulbecco's modified Eagle's minimal essential medium(DMEM, Gifco BRL, Grand Island, $\mathrm{NJ}, \mathrm{USA}$ ) 배지를 사용하여 배양하였으며, 3 일에 한번 씩 계대하여 사용하였다.

\section{Nitric oxide(NO) 측정}

RAW264.7 세포에서의 NO 생성을 확인하기 위해 24 well plate에 $1.5 \times 10^{5}$ cells $/ \mathrm{mL}$ 으로 분주한 후 18 시간 배양하 여 준비하였다. 준비된 세포에 $1 \mathrm{\mu g} / \mathrm{mL}$ 의 lipopolysaccharide (LPS, Sigma-Aldrich, Damstadt, Germany)와 시료를 처리하 여 24시간 배양 후 세포 배양 상등액을 이용하여 $\mathrm{NO}$ 의 생성을 확인하였다. NO의 생성은 Griess reagent를 사용하 여 흡광도 $540 \mathrm{~nm}$ 에서 측정하였다.

\section{Pro-inflammatory cytokine 억제 활성 측정}

Pro-inflammatory cytokine 억제 활성 측정을 위해 RAW264.7 세포를 24 well plate에 $1.5 \times 10^{5}$ cells $/ \mathrm{mL}$ 로 분주 하여 18 시간 배양 후 E. coli 유래 LPS를 $1 \mu \mathrm{g} / \mathrm{mL}$ 로 처리하 여 cytokine의 생성을 유도하였다. Cytokine이 생성된 세포 에 농도별로 시료를 처리하여 24시간 배양 후 상등액을 이용하여 cytokine 생성 억제 활성을 측정하였다. Mouse TNF-a(Invitrogen Corp., Carlsbad, California, USA), IL-1 $\beta$ (R\&D System Inc., Minneapolis, Minnesota, USA), IL-6(Invitrogen Corp., Carlsbad, California, USA) ELISA kit 를 사용하여 측정하였다.

\section{세포 생존율 측정}

RAW264.7 세포에 대한 세포독성 평가는 24 well plate에 $1.5 \times 10^{5}$ cells $/ \mathrm{mL}$ 로 분주하여 18 시간 배양 후 $\mathrm{LPS}$ 를 $1 \mu$ $\mathrm{g} / \mathrm{mL}$ 와 시료를 처리하여 다시 24시간 배양 후 세포 독성을 측정하였다. 24시간 배양된 세포에 WST-1 reagent(Roche
Applied Science, Mannheim, Germany)를 10\%(v/v)로 첨가 하여 4시간 추가 배양한 후 $440 \mathrm{~nm}$ 에서 흡광도를 측정하였 다.

\section{통계분석}

모든 실험은 3회 이상 반복하여 이루어졌으며, 실험 결과 는 각 항목에 따라 평균과 표준편차로 나타내었다. 실험군 과의 차이는 SAS package(Statistical Analysis Program, version 9.1)를 사용하여 Duncan's multiple range test로 평균 을 비교하여 나타내었고, $\mathrm{p}<0.05$ 수준에서 통계적 유의성을 검정하였다.

\section{결과 및 고찰}

\section{꿩의비름 부위별 추출물의 항산화 활성}

각종 질환 발생에 영향을 미치는 것으로 알려진 활성산 소는 비공유 전자를 갖고 있는 불안정한 분자로 세포 구성 성분들과 쉽게 반응하게 된다. 활성산소는 비선택적이고 비가역적으로 지질과산화, 단백질 변성, DNA 변형 등을 일으켜, 염증, 암, 노화, 혈관질환 자가면역질환 등의 각종 질병을 유발하는 것으로 알려져 있다(14-16). 이러한 활성 산소에 대한 꿩의비름 추출물의 항산화 활성은 시료의 전자 공여에 의한 free radical 소거 활성을 측정할 수 있는 $\mathrm{DPPH}$, ABTS, superoxide anion radical 제거능과 산화, 환원 반응 메카니즘을 이용한 FRAP를 측정하였다. 시료는 인삼특작 부 추출물은행에서 분양 받은 뀡의비름 뿌리(HER), 줄기 (HEB), 잎(HEL), 지상부(HEAG) 추출물을 사용하였으며, 부위별 꿩의 비름 추출물 $(100 \mu \mathrm{g} / \mathrm{mL})$ 의 항산화 활성을 측정 하여 활성이 가장 우수한 부위를 선발하여 소재화하고자 하였다.

Table 1. Anti-oxidative activities of HEAG. $\mathrm{SC}_{50}$ value in $\mathrm{DPPH}$, ABTS, and superoxide anion radical scavenging activities of HEAG

\begin{tabular}{lccc}
\hline & & HEAG & $\mathrm{AA}^{1)}$ \\
\hline & DPPH & $16.95 \pm 2.33$ & $8.78 \pm 0.89$ \\
$\mathrm{SC}_{50}{ }^{2}(\mu \mathrm{g} / \mathrm{mL})$ & ABTS & $11.24 \pm 0.98$ & $5.51 \pm 0.63$ \\
& Superoxide anion & $24.93 \pm 2.54$ & $1,259 \pm 87.35$ \\
\hline
\end{tabular}

${ }^{1)}$ Ascorbic acid.

${ }^{2} 50 \%$ Radical scavenging capacity.

꿩의비름 부위별 추출물의 DPPH와 ABTS radical 소거능 을 알아본 결과 Fig. $1 \mathrm{~A}$ 와 같이 $100 \mu \mathrm{g} / \mathrm{mL}$ 의 농도에서 $\mathrm{DPPH}$ radical 소거능은 각각 HER $50 \pm 4.8 \%$, HEL $32 \pm 3.5 \%$, $\mathrm{HEB} 5 \pm 3.8 \%, \mathrm{HEAG}$ 가 $87 \pm 6.1 \%$ 로 나타났으며, 지상부 추 출물인 $\mathrm{HEAG}$ 추출물의 활성이 가장 우수하였다. $\mathrm{ABTS}$ 
(A)

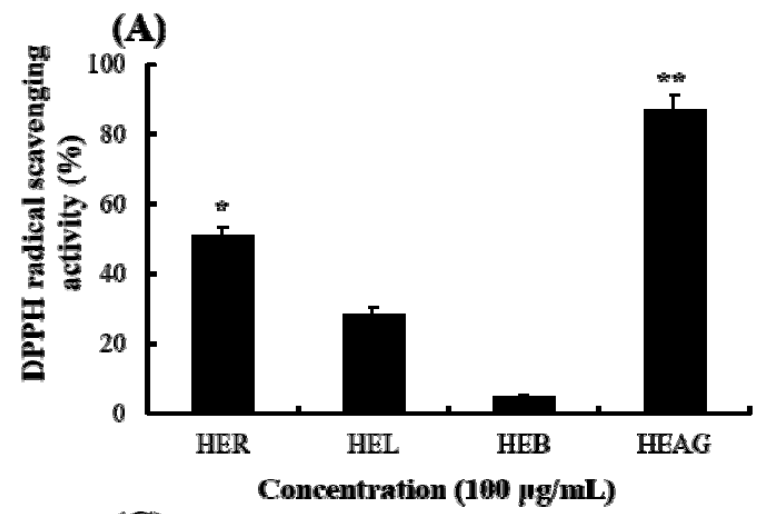

(C)

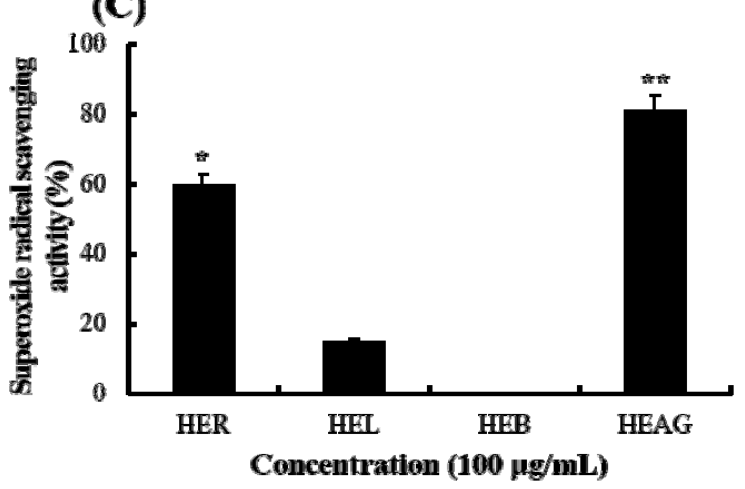

(B)

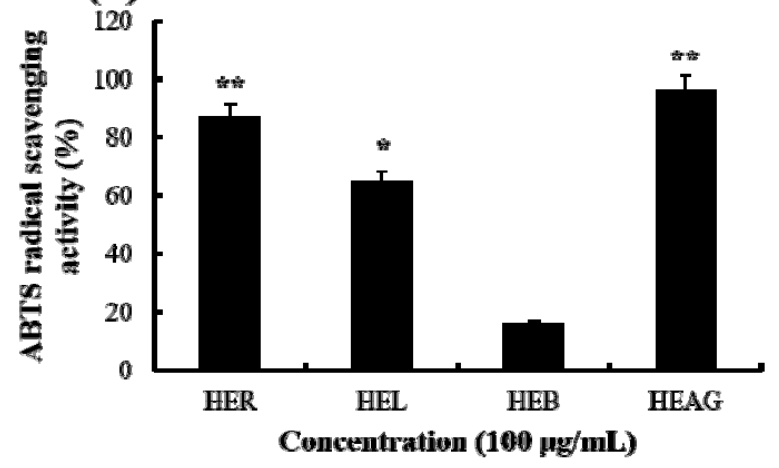

(D)

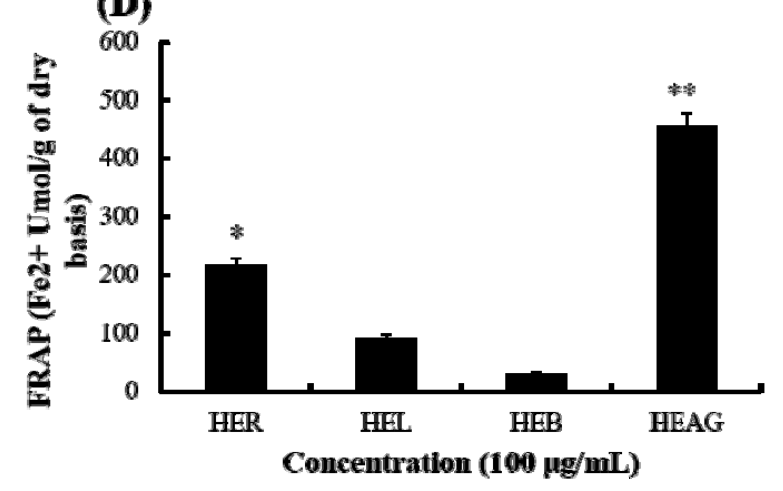

Fig. 1. DPPH (A), ABTS (B), and superoxide anion (C) radical scavenging activities and FRAP(D) of HER, HEL, HEB, and HEAG. The data represent the mean $\pm \mathrm{SD}$ of triplicate experiments. ${ }^{*} \mathrm{p}, 0.05$, ${ }^{*} \mathrm{p}, 0.01$, versus control.

radical 소거 활성 역시 Fig. $1 \mathrm{~B}$ 에서와 같이 $\mathrm{HEAG}$ 는 $96 \pm 5.7 \%$ 로 가장 높았으며 HER $87 \pm 2.5$, HEL $65 \pm 3.4 \%$, HEB $16.3 \pm 2.1, \mathrm{HER}$ 이 $87 \pm 6.9 \%$ 의 ABTS radical 소거 활성 을 보였다. 또한 superoxide anion radical 소거능은 $\mathrm{DPPH}$ 와 $\mathrm{ABTS}$ 에서와 비슷한 양상으로 $\mathrm{HEAG}$ 추출물에서 $81 \pm 4.4 \%$ 로 가장 우수한 라디칼 소거능을 보였으나 $\mathrm{HEB}$ 추출물에 서는 소거능을 확인할 수 없었다(Fig. 1C). 호기성 세포의 효소 및 비효소적 단계에서 생성되는 독성이 강한 superoxide anion radical은 노화와 관련된 산화 반응의 개시 단계에서 hydrogen peroxide, hydroxyl radical, singlet oxygen 등과 같은 다른 활성산소종의 생성에 관여하여 지 질, 단백질, $\mathrm{DNA}$ 등에 산화적 손상을 유도하는 것으로 알려 져 있다(17,18).이러한 superoxide anion radical 등은 페놀성 화합물들에 의해 소거된다는 보고가 있으며(19), 본 실험 결과 지상부추출물인 $\mathrm{HEAG}$ 에서 $\mathrm{DPPH}, \mathrm{ABTS}$, superoxide anion radical 소거능이 높은 것은 총 폴리페놀 함량이 높기 때문인 것으로 추측된다.

또한 FRAP assay에 의한 뀡의비름 부위별 추출물들의 항산화 활성을 측정하였다(Fig. 1D). FRAP assay는 ferric $\left(\mathrm{Fe}^{3+}\right) \mathrm{TPTZ}$ complex가 ferrous $\left(\mathrm{Fe}^{2+}\right)$ 형태로 환원될 때 발생 하는 청색파장을 흡광도 $593 \mathrm{~nm}$ 에서 측정하는 방법으로 라디칼 소거방식의 항산화 측정법과는 다른 메커니즘의 항산화 측정법이다(20). FRAP assay 결과 HEAG 추출물
$100 \mu \mathrm{g} / \mathrm{mL}$ 에서 $455 \pm 21.3 \mathrm{Fe}^{2+} \mu \mathrm{mol} / \mathrm{g}$ 으로 가장 높았으며, 이는 대조군인 vitamin $\mathrm{C}$ 의 처리농도 $15 \mu \mathrm{gg} / \mathrm{mL}(487 \pm 33.4$ $\mathrm{Fe}^{2+} \mu \mathrm{mol} / \mathrm{g}$ )과 비숫한 활성으로 항산화 활성이 매우 우수함 을 알 수 있었다. 꿩의비름 부위별 추출물을 이용한 항산화 활성 측정에서 지상부 추출물인 $\mathrm{HEAG}$ 의 활성이 가장 우수 하였으며 HEAG의 DPPH, ABTS, superoxide anion radical 의 $50 \%$ 소거 활성인 $\mathrm{SC}_{50}(\mathrm{\mu g} / \mathrm{mL})$ 은 Table1에서와 같이 각 각 $16.95 \pm 2.33,11.24 \pm 0.98,24.93 \pm 2.54$ 로 나타났다.

\section{$\mathrm{HEAG}$ 의 총 폴리페놀 및 총 플라보노이드 함량 분석}

항산화, 항암, 항염 등의 생리 활성을 갖는 것으로 알려진 페놀성 화합물은 식물계에 널리 분포되어 있는 2 차 대사산 물의 하나로 다양한 분자량과 구조를 가지고 있다. 이러한 페놀성 화합물의 함량을 항산화 활성이 가장 우수하였던 꿩의비름 지상부 추출물(HEAG)에서 gallic acid를 기준물 질로 사용하여 측정하였다(Fig. 2). HEAG의 총 폴리페놀 함량은 $238.5 \pm 18.9 \mathrm{mg} / \mathrm{g}$ gallic acid equivalent로 높은 수치 를 나타내었다. 이는 항산화 활성이 우수하고 phenolic compound를 다량함유하고 있는 것으로 알려진 감귤 추출 물 $(150 \pm 19.4 \mathrm{mg} / \mathrm{g}$ gallic acid equivalent)과 비교해서도 높은 수치이다(21). 또한 자연적으로 생성되는 페놀성 화합물 중 가장 큰 그룹중의 하나로 담황색 또는 노란색 계통의 화합물인 플라보노이드(22-24)의 함량은 quercetin을 기준 
물질로 사용하여 측정하였다. HEAG의 총 플라보노이드 함량 역시 $189 \pm 15.21 \mathrm{mg} / \mathrm{g}$ quercetin equivalent로 높게 나타 났다. 꿩의비름 추출물에 다량 함유되어 있는 페놀성 화합 물은 분자 내에 phenolic hydroxyl 기를 가지고 있는 방향족 화합물로 단백질 및 기타 거대 분자들과 쉽게 결합하여 $\mathrm{HEAG}$ 의 항산화 및 항염 활성에 영향을 줄 것으로 여겨진 다.

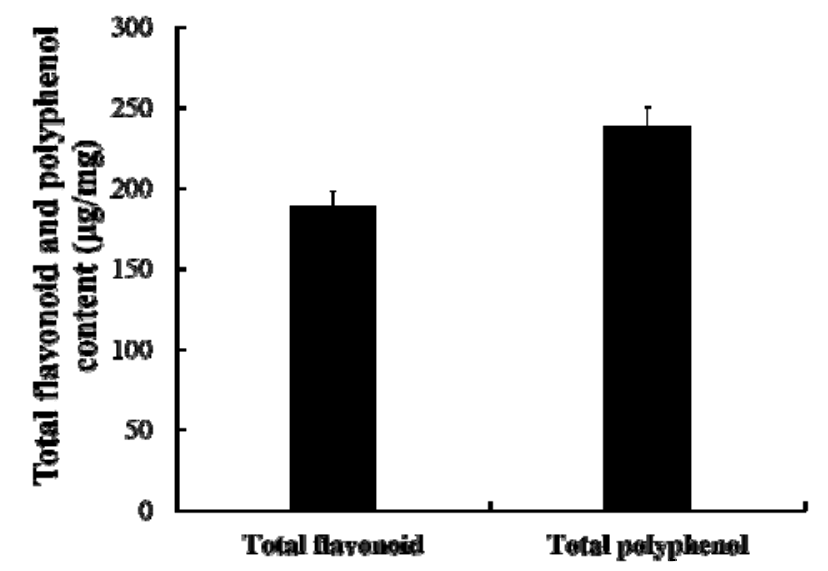

Fig. 2. Total flavonoid and total polyphenol contents of HEAG.

Total flavonoid and polyphenol contents were expressed as quercetin and gallic acid equivallent, respectively. The data represent the mean $\pm \mathrm{SD}$ of triplicate experiments. ${ }^{*} \mathrm{p}<0.05,{ }^{* *} \mathrm{p}<0.01$,

$\mathrm{HEAG}$ 의 NO와 염증성 cytokine 생성 억제

폴리페놀을 다량 함유하고 있는 꿩의비름 지상부 추출물 인 HEAG에 대한 항염 활성 측정을 위해 대식세포인 RAW264.7을 LPS로 염증을 유도한 후 생성되는 NO와 염증 성 cytokine인 TNF-a, IL-1ß, IL-6의 생성 억제 효과를 확인 하고자 하였다. 염증반응은 생체나 조직에 물리적 작용이

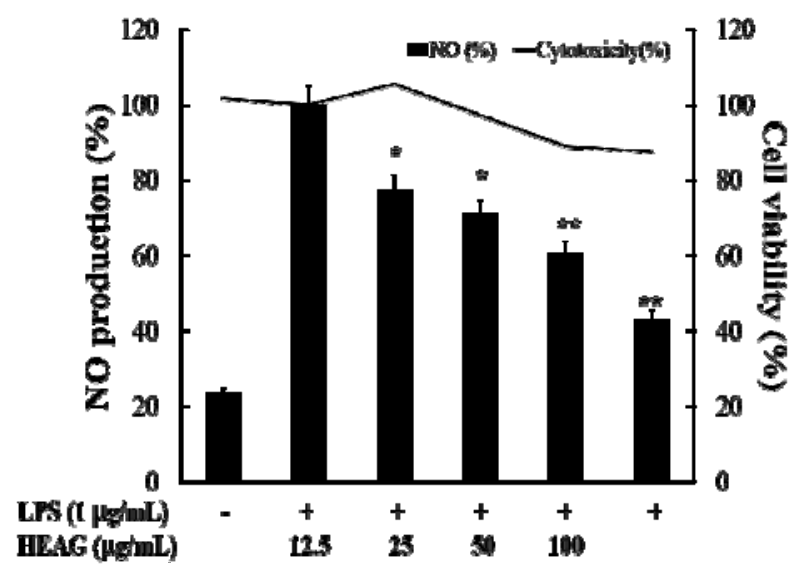

Fig. 3. Inhibitory effects of HEAG on the production of NO in LPS-stimulated RAW264.7 murine macrophage cell.

RAW264.7 cells were treated with extracts and LPS $(1 \mu \mathrm{g} / \mathrm{mL})$ for $24 \mathrm{~h}$. LPS(-), PBS without LPS; LPS (+), PBS with LPS. The data represent the mean \pm SD of triplicate experiments. ${ }^{*} \mathrm{p}<0.05$, ${ }^{*}{ }^{*}<0.01$, versus LPS alone.
나 화학적 물질, 세균 감염 등에 의해 나타나는 생체반응으 로, 일단 자극이 가해지면 국소적으로 염증성 성분과 같은 혈관 활성 물질이 유리되어 부종, 발열, 조직손상, 세포증식 등 여러 질환을 발생 시키는 원인이 된다(25-27).

면역반응에서 중요한 역할을 하는 $\mathrm{NO}$ 의 과도한 생성은 염증을 유발하는 매개인자가 되므로 RAW264.7 대식세포 에서 LPS로 염증 유발하여 $\mathrm{NO}$ 의 생성을 급속히 증가시킨 후 HEAG를 농도 별로 처리하였다. 내독소로 알려진 LPS에 의해 염증이 유발된 RAW264.7 세포에 HEAG를 처리하였 을 때 농도 의존적으로 $\mathrm{NO}$ 의 생성이 억제되었고, $100 \mu$ $\mathrm{g} / \mathrm{mL}$ 의 농도로 처리시 LPS 처리군 대비 세포 독성 없이 $60 \%$ 감소하여 $\mathrm{HEAG}$ 가 $\mathrm{NO}$ 의 생성 억제에 관여함을 알

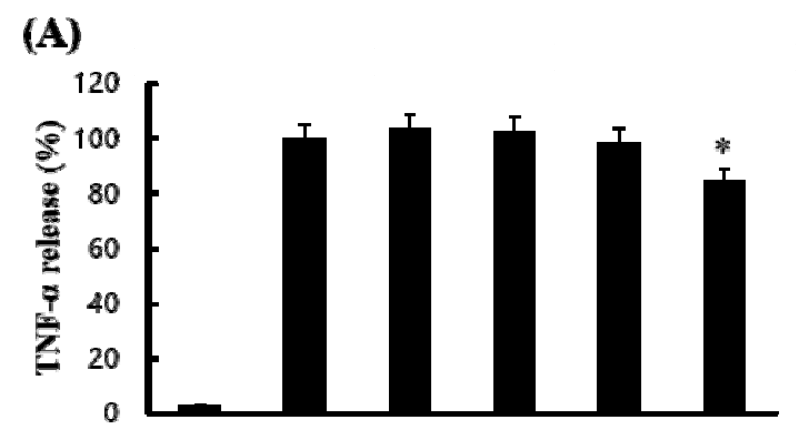

(B)

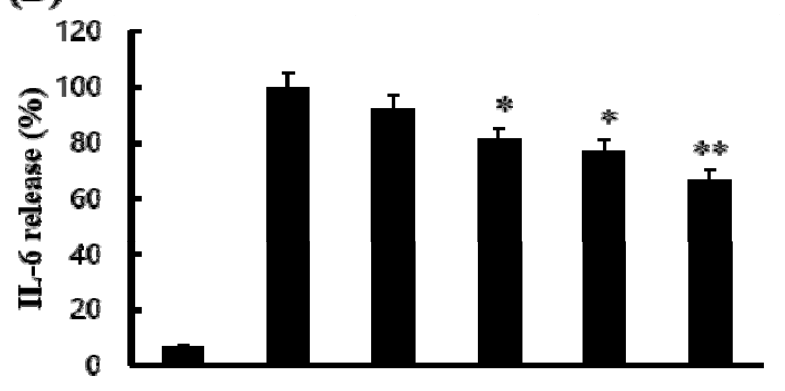

(C)

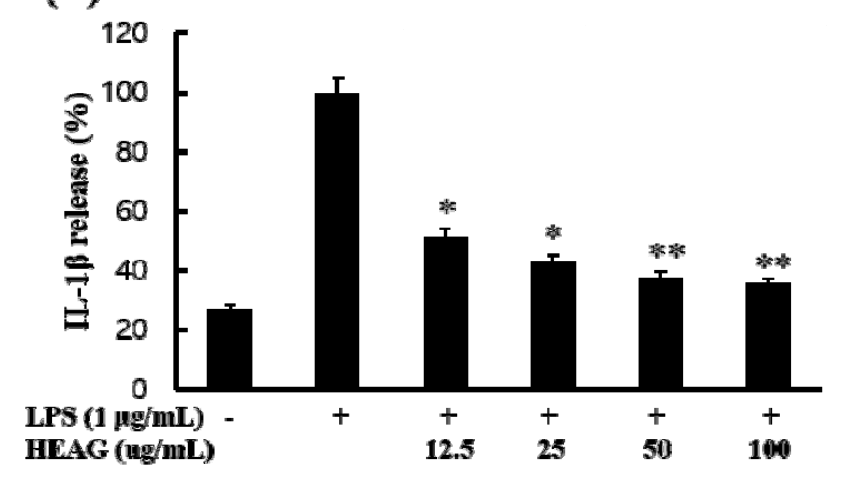

Fig. 4. Inhibitory effects of HEAG on the production of TNF-a (A), IL-6 (B), and IL-1 $\beta$ (C) in LPS-stimulated RAW264.7 murine macrophage cell.

RAW264.7 cells were treated with extracts and LPS $(1 \mu \mathrm{g} / \mathrm{mL})$ for $24 \mathrm{~h}$. The concentrations of TNF- $a$, IL-6, and IL-1 $\beta$ were measured by ELISA. LPS(-), PBS without LPS; LPS (+), PBS with LPS. The data represent the mean \pm SD of triplicate experiments. ${ }^{*} \mathrm{p}<0.05,{ }^{* *} \mathrm{p}<0.01$, versus LPS alone. 
수 있었다(Fig. 3).

또한 $\mathrm{HEAG}$ 의 염증 유발 사이토카인의 생성 억제 활성을 알아보기 위해 RAW264.7 세포에 LPS를 18시간 처리하여 TNF-a, IL-1ß, IL-6 생성을 유도하고 HEAG를 12.5, 25, 50, $100 \mathrm{\mu g} / \mathrm{mL}$ 의 농도별로 처리하여 생성 억제 활성을 측정하 였다. 그 결과 Fig. 4에서와 같이 LPS 처리군 대비 염증성 사이토카인의 생성이 농도 의존적으로 억제하는 것을 확인 할 수 있었다. 염증성 사이토카인 중 TNF-a는 감염초기 호중구와 단핵구가 감염부위로 이동하도록 자극하는 염증 반응 조절에 관여하는 중요한 인자로 $\mathrm{HEAG}$ 추출물은 100 $\mu \mathrm{g} / \mathrm{mL}$ 에서 $15 \%$ 정도의 저해 활성을 확인할 수 있었으나 피부노화와 관련된 염증 유발인자로 알려진 IL-6와 IL-1 $\beta$ 에 대해서는 $100 \mu \mathrm{g} / \mathrm{mL}$ 에서 각각 $33 \%$ 와 $64 \%$ 의 우수한 억제활성을 확인 할 수 있었다(28).

\section{요 약}

피부병 치료에 사용되던 꿩의비름 추출물을 항산화 및 항염 효능을 지니는 천연물 소재로 활용하기 위해 꿩의비름 의 뿌리(HER), 잎(HEL), 줄기(HEB), 지상부(HEAG) 추출 물에 대해 항산화 활성을 측정한 결과 지상부 추출물인 $\mathrm{HEAG}$ 에서 DPPH, ABTS, superoxide anion radical 소거 활 성이 가장 우수하였으며, FRAP 활성 역시 HEAG에서 가장 우수하였다. 항산화 활성이 가장 우수한 $\mathrm{HEAG}$ 의 총 폴리 페놀 함량을 측정한 결과 $235.5 \pm 18.96 \mathrm{mg} / \mathrm{g}$ gallic acid equivalent로 항산화 및 항염 활성을 갖는 것으로 알려진 페놀성 화합물을 다량 함유하고 있는 것을 확인할 수 있었 다. 또한 마우스 대식세포인 RAW264.7 세포를 이용하여 항염 활성에서는 $\mathrm{NO}$ 의 생성을 억제하였으며 염증성 사이 토카인인 IL-1ß의 생성 억제 화성이 가장 높았다. 꿩의비름 추출물은 항산화 및 항염 활성의 천연물 소재로 활용이 가능 할 것으로 여겨진다.

\section{감사의 글}

본 성과물은 농촌진흥청 연구사업(세부과제: PJ01093402) 의 지원에 의해 이루어진 것입니다.

\section{References}

1. Nanes MS (2003) Tumor necrosis factor-a: molecular and cellular mechanisms in skeletal pathology. Gene, 321, $1-15$

2. Jeon AL, Kim JE, Lee NH (2017) Whitening and anti-inflammatory constitutes from the extract of Citrullus lanatus vines. J Soc Cosmet Sci Korea, 53-60

3. Kim, SS, Oh HJ, Baik JS, Oh TH, Yun PY, Kim CS, Lee NH, Hyun CG (2008) Chemical composition and biological activities of Elsholtzia splendens essential oil. J Appl Biol Chem, 51, 69-72

4. Kim SS, Hyun CG, Choi YH, Lee NH (2013) Tyrosinase inhibitory activities of the compounds isolated from Neolitsea aciculata (Blume) Koidz. J Enzyme Inhib Med Chem, 28, 685-689

5. Shih MF, Cheng YD, Shen CR, Cherng JY (2010) A molecular pharmacology study into the anti-inflammatory actions of Euphorbia hirta L. on the LPS-induced RAW 264.7 cells through selective iNOS protein inhibition. J Nat Med, 64, 330-335

6. Tsatsanis C, Androulidaki A, Venihaki M, Margioris AN (2006) Signalling networks regulating cyclooxygenase-2. Int J Biochem Cell Biol, 38, 1654-1661

7. Kim MJ, Kim SS, Park KJ, An HJ, Choi YH, Lee NH, Hyun CG (2016) Methyl j asmonate inhibits lipopolysaccharide-induced inflammatory cytokine production via mitogen-activated protein kinase and nuclear factor- $\kappa B$ pathways in RAW 264.7 cells. Die Pharmazie, 71, 540-543

8. Ham YM, Yoon WJ, Lee WJ, Kim SC, Baik JS, Kim JH, Lee GS, Lee NH, Hyun CG (2015) Anti-inflammatory effects of isoketocharbroic acid from brown alga, Sargassum micracanthum. EXCLI J, 14, 1116-1121

9. Yoon ES (1997) Effect of plant growth regulators on plant regeneration from leaf and stem explant cultures of Sedum erythrostichum Miq.. Korean J Plant Tissue Culture, 24, 285-289

10. Blois MS (1958) Antioxidant determinations by the use of a stable free radical. Nature, 181, 1199-1200

11. Liu F, Ooi VEC, Chang ST (1997) Free radical scavenging activity of mushroom polysaccharide extracts. Life Sci, 60, 763-771

12. Singleton VL, Orthofer R, Lamuela-Raventos RM (1999) Analysis of total phenols and other oxidation substrates and antioxidants by means of Folin-Ciocalteu reagent. Methods Enzymol, 299, 152-178

13. Nieva Moreno MI, Isla MI, Sampietro AR, Vattuone MA (2000) Comparison of the free radical-scavenging activity of propolis from several regions of Argentina. J Ethnopharmacol, 71, 109-114

14. Devasagayam TPA, Tilak JC, Boloor KK, Sane KS, Ghaskadbi SS, Lele RD (2004) Free radicals and 
antioxidants in human health: Current status and future prospects. J Assoc Physicians India, 52, 794-804

15. Valko M, Leibfritz D, Moncol J, Cronin MT, Mazur M, Telser J (2007) Free radicals and antioxidants in normal physiological functions and human disease. Int $\mathbf{J}$ Biochem Cell Biol, 39, 44-84

16. Maeda H, Akaike T (1998) Nitric oxide and oxygen radicals in infection, inflammation, and cancer. Biochemistry (Mosc), 63, 854-865

17. Samak G, Shenoy RP, Manjunatha SM, Vinayak KS (2009) Superoxide and hydroxyl radical scavenging actions of botanical extracts of Wagatea spicata. Food Chem, 115, 631-634

18. Gulcin I, Berashvili D, Gepdiremen A (2005) Antiradical and antioxidant activity of total anthocyanins from Perilla pankinensis decne. J Ethmopharmacol, 101, 287-293

19. Joung YM, Park SJ, Lee KY, Lee JY, Suh JK, Hwang SY, Park KE, Kang MH (2007) Antioxidant and antimicrobial activities of Lilium species extracts prepared from different aerial parts. Korean J Food Sci Technol, 39, 452-457

20. Choi JS, Kim HY, Seo WT, Lee JH, Cho KM (2012) Roasting enhances antioxidant effect of bitter melon (Momordica charantia L.) increasing in flavan-3-ol and phenolic acid contents. Food Sci Biotechnol, 21, 19-26

21. Kim SS, Park KJ, An HJ, Choi YH (2017) Phytochemical, antioxidant, and antibacterial activities of fermented Citrus unshiu byproduct. Food Sci Biotechnol. 26, 461-466
22. Kwak JH, Choi GN, Park JH, Kim JH, Jeong HR, Jeong $\mathrm{CH}$, Heo HJ (2010) Antioxidant and neuronal cell protective effect of purple sweet potato extract. J Agriculture Life Sciences, 44, 57-66

23. Lee SY, Shin YJ, Park JH, Kim SM, Park CS (2008) An analysis of the Gyungokgo's ingredients and a comparison study on anti-oxidation effects according to the kinds of extract. Kor J Herbology, 23, 123-136

24. Kang MH, Choi CS, Kim ZS, Chung HK, Min KS, Park CG, Park HW (2002) Antioxidative activities of ethanol extract prepared from leaves, seed, branch and aerial part of Crotalaria sessiflora L.. Korean J Food Sci Technol, 34, 1098-1102

25. Yoon WJ, Lee JA, Kim KN, Kim JY, Park SY (2007) In vitro anti-inflammatory activity of the Artemisia fukudo extracts in murine macrophage RAW 264.7 cells. Korean J Food Sci Technol, 39, 464-469

26. Fenton MJ, Golenbock DT (1998) LPS-binding proteins and receptors. J Leukocyte Biol, 64, 25-32

27. Shih MF, Cheng YD, Shen CR, Cherng JY (2010) A molecular pharmacology study into the anti-inflammatory actions of Euphorbia hirta L. on the LPS-induced RAW 264.7 cells through selective iNOS protein inhibition. J Nat Med, 64, 330-335

28. Choe SI, Jo MJ, Kim SC, Byun SH (2008) Inhibitory effect of Sunbanghwalmyungeum $\mathrm{MeOH}$ extract on pro-inflammatory mediator in lipopolysaccharide-activated Raw 264.7 cells. Kor J Herbology, 23, 11-18 